\title{
BULGARIAN INDUSTRIAL POLICY - A BRIEF REVIEW OF ITS DEVELOPMENT
}

\author{
R. Angelova* \\ Industrial Business and Entrepreneurship Department, Trakia University, Stara Zagora, Bulgaria
}

\begin{abstract}
In the historical development of the Bulgarian industrial policy after Bulgaria liberation from the Turkish slavery to the present days, several major development periods clearly stand out. They differ from each other with their specific in terms of economic governance. In the submitted paper, the author makes a brief review of each of them, highlighting their most important features.
\end{abstract}

Key words: industrial policy

In the historical development of Bulgarian industrial policy, several key stages can be identified. The main criterion for their differentiation is the "built-in and functioning in the different stages of the economy management system"(1):

- $\quad$ First period - From the Liberation Of Bulgaria from Turkish slavery until 1944

- $\quad$ Second period - from 1947 to 1989

- $\quad$ Tird period - after 1990

A. First period - From the Liberation Of Bulgaria from Turkish slavery until 1944

The beginning of the industrial policy in Bulgaria is set by the Finance Minister Grigor Nachvich in 1883, who raised the issue of "encouraging the local industry" (2) before the Third Ordinary National Assembly. In 1892, he introduced a Local Industry Incentive Bill, which was adopted in 1895. A few years later - in 1909, and in 1928, it was revised, further developed and changed to a Law for the Promotion of Local Industry. It specifies:

- $\quad$ Conditions for obtaining benefits: "Enterprises using mechanical power engines of 10 horsepower; up to ten employees in at least six months of the year employ; machinery and equipment worth at least twenty thousand gold leva (3);

- Industrial brances - 23 industrial branches, grouped into 10 main groups (3);

- $\quad$ The amount and nature of benefits the benefits provided by law are related to:

*Correspondence to: Rumyana Angelova, Trakia University, Stara Zagora, Industrial Business and Entrepreneurship Department,

Phone:+35942699432, e-mail:rumi2002@abv.bg
- favorable customs tariffs; free acquisition of state, district and municipal factories; reduced tax rates; reduced tariffs when using rail; priority in government and public procurement, etc .;

- $\quad$ Term for using the benefits provided 15 years.

The benefits created favor the development of industrial production. The capital invested in the promoted industry reached BGN 7,600 million in 1934 compared to BGN 6,441 million in 1929. Incentive measures and the global economic crisis have led to a reduction in the domestic market (4). The state of "saturation" is solved with the formulated for this purpose industrial policy tasks of the Union of Bulgarian Industrialists in 1930: $1 /$ termination of the granting of benefits to new enterprises; 2 / directing part of existing capital to new enterprises; 3 / facilitating the operation of industrial enterprises and others. For this period, the formation of cartel structures, whose aim was not so much profits, but the prevention of bankruptcy by maintaining high prices, which compensated for the incomplete use of production capacity, was characteristic. This necessitated the adoption of the Law on Cartels and Monopoly Prices in 1931.

In 1936 the new Law on Industry, also called the "Bulgarian Industry Constitution" (5) comes into force. It highlights some specific features of industrial production (typical of the large industry) related to the quantity and quality of manual labor input as well as the division of labor between the executive and managerial staff of the enterprise. It eliminates 
the benefits of the Law on the Promotion of Local Industry and defines the rights and obligations of individual enterprises and industries.
The above-mentioned Laws concern the direct (administrative) promotion of Bulgarian industry. Parallel to it, the industry production is also promoting indirectly :

a) Customs Tariffs - new tariffs have been developed in 1922 (Table 1):

Table 1. Customs tariffs for the period $1904-1936$ (for $100 \mathrm{~kg}$ in gold leva)

\begin{tabular}{|l|l|l|l|l|l|l|}
\hline & Goods & $\mathbf{1 9 0 4}$ & $\mathbf{1 9 2 2}$ & $\mathbf{1 9 2 6}$ & $\mathbf{1 9 3 6}$ & \\
\hline & & & & & & \\
\\
\hline
\end{tabular}

Source: Toshev, D. Industrial Policy of Bulgaria after the First World War. Varna, 1943. p.52

The higher tariffs have a fiscal purpose but they also fulfill a protectionist goal, thus contributing to the development of local industry. A law prohibits the import of certain luxury goods, as well as of "non-essential" necessities, which also contributed to the development of their production in Bulgaria.

b) Foreign trade policy - for the period after the liberation until 1944, many factors influenced on the industrial policy of Bulgaria, such as: World War I, the restrictions laid down in the Neuilly Treaty, the world economic crisis in 1929, the upcoming Second World War and others. Bulgaria entered into contracts for the import of some industrial goods with Germany, and later with Italy and Czechoslovakia, the import duties were considerably reduced. For other goods such as shoes, textiles, hardware, etc. discounts were negligible.

c / Credit policy - lending to industry for the period under review was mainly done by private foreign and local banks and less than the BNB, which served primarily the stateowned financial holding. High interest rates (between 16\% and 18\%), credit limitations and timeframes (mostly short-term loans up to 3 years) and collateral (guarantee, pledge, mortgages) are the reason for the low interest in financing industrial productions Through bank credit, and mostly recourse to selffinancing in the form of commodity credits between businesses.

d / Tax policy - the promotion of industry through the abolition of a number of taxes (building tax, tax-occupation, etc.) is enshrined in the previously mentioned Laws for the Promotion of Local Industry. According to some prominent financiers of that time, "taxes in Bulgaria are low because they are between 5 and 15 per thousand, when in Yugoslavia they are from 15 to 25 per thousand" (6). The tax burden is targeted at consumers because it is considered to be unfavorable to large-scale taxation of large capital as long-term investments are made there.

e) Development of vocational education - the development of industrial production in Bulgaria raises the need for specialists with appropriate vocational education. A number of commercial and industrial education laws of this period (1907, 1924 and 1934) call for the establishment of new practical schools. The training is free of charge. Business owners were obliged to release their workers who had visited them. One of the objectives of specialized schools is also the acquisition of skills to enable the self-employment of a profession. In this case, the state provided support in the form of guarantees when the person applied for a loan when starting their own business. However, the results achieved in education reforms are assessed as insufficient (7), although the number of young graduates in vocational schools has increased over time: in 1928 - 2750; 1935- 4014; 1939 - 6936 people (4). The local industry is still too weak and does not have enough experience and resources to influence the program and training in industrial schools.

f/ Agrarian policy - although there are no normative documents regulating the reconciliation between Bulgaria's industrial 
and agrarian policy, there has been a tendency towards the development of those indigenous industries using agricultural raw materials. In 1934, the state adopts a number of legislative measures through which it monopolizes the trade with Bulgarian agricultural products. Their production is promoted by imposing high, stable prices on the domestic market. The stock they accumulate allows and satisfies the development of the local industry. The forthcoming Second World War, however, has led to a rise in agricultural product prices, which outstripped those of industrial goods. The state pledges to all industrial firms processing indigenous raw materials to supply them from the domestic market. If these are missing in the country, deliveries are made from abroad, with special agreements being made for this purpose. The benefit to local industries is also the loss of commitment to reloading and storing perishable agricultural products. They undertake to place on their products a label that they are made from raw materials and native production. On the other hand, their producers are encouraged by financing in the form of advances.

g) Other measures stimulating the development of the industry - legislative initiatives related to the Chambers of Commerce and Industry, trademarks, patents and inventions, etc., are also targeted at events aimed at stimulating the industry, etc.

Industrial production in Bulgaria during the period after the Liberation until 1944 marks some progress. The basis for this statement is the dynamics of the indicators (8):

$\checkmark \quad$ Investments in fixed capital in industry (in 1929 - amounted to BGN 757 million, while in 1940 it reached BGN 1246 million);

$\checkmark \quad$ Index of industrial production (169 - in 1940, compared to 100 - in 1929);

$\checkmark \quad$ The average annual growth rate of the index of industrial production - for the period $1934-1941$ - adopts a value of $6.9 \%$.

Nevertheless, during this first stage of its development, Bulgarian industrial policy is assessed as unsatisfactory. Industry in the mid1940 s accounts for only $8 \%$ of national income. During the period 1939 - 1941, the leading position occupied the food industry, incl. tobacco - with a share of $58 \%$ of total industrial output followed by textiles - by $19 \%$; leather, rubber, woodworking - $4 \%$; metalworking - 3\%, etc. Compared to the other highly developed European countries, our country lags between 10 and 30 times by indicators such as: industrial production per capita, employment in industry, share of industry in national income, etc.

\section{B. Second period - from 1947 to 1989}

Bulgaria's industrial policy during this period is subordinate to the "socialist model" of government, which includes planning economy, a state monopoly in foreign trade, agrarian reform and the elimination of free market competition. Economy management is centralized, based on five-year Soviet model plans. The emphasis is on the heavy industry, giving priority to power generation, mining, metallurgy, machine building and chemical production. There are a large number of industrial enterprises, mainly concentrated in the big cities of the country. Gradually Bulgaria turns from an agrarian to an industrially developed country. In 1979 industry accounts for $68 \%$ of the public product and $60 \%$ of the national income (in $1939-19 \%$ and $15 \%$ respectively) (9).

The socialist model of Bulgarian industrial policy is characterized by some features that lead to a number of problems and failures:

1/ Market functions are assumed by central administrative bodies - enterprise management is entrusted to various government bodies and ministries (mainly the Ministry of Industry and Crafts). With the establishment of the CCIB in 1949, the country's economic contacts are limited to the USSR and the eastern European countries, with a clearing form of commodity exchange taking place between them. Having a secure market reduces the drive for competitive production.

2/ Accumulation of a large part of the existing enterprises in associations - By Decree 20 of the Council of Ministers of 1948, of 2273 enterprises is planned to close 994 . Thus, in 1952, The Ministry of Industry already has 912 enterprises, which are included in 17 unions (10).

3/ Impact and dictate of the Bulgarian Communist Party on the producers - the administrative guides of enterprises and institutions are controlled through primary party organizations on the ground. Qualification and professionalism of senior staff are secondary factors.

4/ Non-compliance of the production capacities with the natural and energy resources of the country - on the one hand, the new industrial enterprises are facing the problem of working with imported raw materials, as the Bulgarian ones are limited or of low quality. On the other hand, some of them are built in cities located inside the country, which is associated with high transport costs and high cost of production.

5/ Particular importance is attached to machine-building, through which it seeks to 
achieve a high degree of "automation, specialization, typing and series production in all sectors of the economy". The main problem here lies in the realization of the output. The domestic needs of the country are too small for the scale of new businesses. On the other hand, the quality of manufactured products is low and unacceptable for some of the CMEA (The Council for Mutual Economic Assistance) partners.

\section{Tird period - after 1990}

The disintegration of the CMEA after 1990 leads to the liberalization of free trade in the countries of Central and Eastern Europe. The deepening globalization raises the question of the competitiveness of production with even greater severity, as the transactions are already carried out under the rules of a free market economy. A large part of the ineffective stateowned enterprises are facing the dilemma of being closed down or privatized.

Bulgarian industrial policy is subject to the principles adopted by the Washington Consensus (11), which impose: liberalization of financial markets, removal of barriers to market competition of goods, privatization of stateowned enterprises, removal of barriers to foreign direct investment, etc. An active process of complete restructuring of the economy, in particular of the industry as its main branch, is underway. Parallel to mass privatization processes, restitution processes are under way in Bulgaria. All this leads to a reduction in the number of industrial enterprises, especially in the strategic sectors - machine building, metallurgy, chemical industry, etc.

Under the transition to a market economy, industrial policy pursued by the state has two main tasks (12):

1/ Establishing an adequate market environment to stimulate the restructuring of the economy.

2/ Formation of the structural profile of the industrial sector.

During this period, some basic laws were adopted that provide the legal framework for reforms.: the Law on Transformation and Privatization of State and Municipal Enterprises; Private Business Act; Intellectual Property Law; State Enterprise Management Act and others. Economic regulations are linked to changes in tax rates, interest rate and credit policies, customs duties and so on. Institutional reforms aim at autonomy of business and demonopolization of the public sector.
After 1999 Bulgaria's industrial policy follows EU requirements in relation to the preparation and accession of the country to the European Community. In 2001, A National Economic Development Plan 2000-2006 has been adopted, which envisages increasing competitiveness in three major sectors of the economy: industry, tourism and SMEs. The strategic goal of industrial policy stated in this document is "to build dynamic and competitive production subsectors through the implementation of two instruments: privatization and the establishment of new production enterprises using Bulgarian and foreign capital" (13).

\section{REFERENCES}

1. Deneva, A., T. Lichev, V. Hristova . Contemporary projections of industrial policy. / Scientific Research Almanac. "D.A.Tcenov"Academy of Economics Svishtov, 2013, p.252.

2. Yaranov, A. Stopanskata politika na Bulgaria. Sofia, 1934. p. 4

3. Vladigerov, T. Promishlena politika. Sofia, 1940. p. 12 - 71

4. Toshev, D. Industrial Policy of Bulgaria after the First World War. Varna, 1943.

5. Bobchev, K., Bulgarsko ikonomichesko druzhestvo, XXXV, p. 449

6. Tcholakov, St., Danachnoto naprezhenie na edin narod $\mathrm{v}$ mirno I vav voenno vreme. Varna, 1940. p.79

7. Nikolov, P. Professional and industrial education in Austria and Germany. 1933, pp. 144-145, issue of the Ministry of Commerce, Industry and Labor.

8. Berov, L. Development of the Bulgarian Industry. 1834 - 1947 - 1989. Sofia. 1990.

9. Ivanov, R. National Economy during the Age of Socialism (1949 - 1989) // Dialogue Magazine. SA DA Tsenov - Svishtov, 4, 2007.

10. Marcheva, I. Problems of Modernization in Socialism: Industrialization in Bulgaria. // Studies on the History of Socialism in Bulgaria - 1944 - 1989. Center for Historical and Political Studies. Sofia. 2010.

11.. Williamson,J., What Washington Means by Policy Reform. Peterson Institute for International Economics, Washington, 1990.

12. Nikolov, N. Government regulation in the conditions of transition to market economy and structural reform in industry. Materials from the International Conference "Industrial Organization and Entrepreneurship in Transition Conditions", Albena, 1995.

13. National Economic Development Plan 2000 2006. Summary, Project May 2001 (Reflected comments of the European Commission, July 2001). 